\title{
IDENTIFICATION OF VIBRIOSIS FROM SEAWEED CULTURE IN LOMBOK, WEST
} NUSA TENGGARA

\author{
Dewi Nur'aeni Setyowati ${ }^{1{ }^{*}}$, Nunik Cokrowati ${ }^{1}$ \\ ${ }^{1}$ Aquaculture Study Program, Faculty of Agriculture, Mataram University, Pendidikan St 37, \\ Mataram, Nusa Tenggara Barat, Indonesia
}

*Correspondence :

dewins@unram.ac.id

Received : 2021-05-21

Accepted : 2021-06-23

Keywords :

ice-ice, identification, seaweed, vibrio

\begin{abstract}
The aim of the study was to identify vibrio disease in Eucheuma cottonii samples which had the characteristics of ice-ice disease, namely the thallus was whitish and broken. The research was conducted at two locations in Lombok, namely in Ekas Bay and in the waters of Buwun Mas Village. The samples were identified as vibrio bacteria at the Sekotong Marine Aquaculture Center using biochemical methods. The results showed that vibrio bacteria were associated with ice-ice disease in the observed seaweeds. The types of vibrio bacteria that cause ice-ice disease in samples in Ekas Bay and Buwun Mas are Vibrio parahaemolyticus, Vibrio alginolyticus, and Vibrio damsela.
\end{abstract}

\section{INTRODUCTION}

Seaweed is a fishery commodity that has important economic value. The export value of seaweed in 2017 was 192,000 tons of the total export of fishery commodities of 382,000 tons. Meanwhile, the export value of seaweed is 205 million USD (Ministry of Marine Affairs and Fisheries, 2018). According to Widiastuti (2004) in Bhernama (2019), Indonesia is known as a producer of seaweed with good quality in the world. Seaweed can be used as industrial raw materials, cosmetics, ice cream, and medicine.

One of the types of seaweed that is widely cultivated and has important economic value is Eucheuma cottonii or also known as Kappaphycus alvarezii (Setyowati et al., 2017).

West Nusa Tenggara (NTB) is one of the provinces with potential for seaweed cultivation. Land for seaweed cultivation has only been utilized for 13,672, ha of the total potential area for seaweed cultivation of 28,490 ha (Department of Marine Affairs and Fisheries of NTB Province, 2015).

One of the obstacles in seaweed cultivation is caused by disease attacks (Setyowati et al, 2017). Research by Largo (2002) explains that ice-ice disease in seaweed is caused by one of the bacteria Vibrio sp. Diseases caused by the bacteria Vibrio sp. called vibriosis (Setyowati, 2018). Types of vibrio that can cause vibriosis include Vibrio alginolyticus, V. anguillarum, and V. vulnificus. Therefore, identification of vibrio disease that attacks seaweed needs to be done.

\section{METHODOLOGY}

The research was carried out by taking samples of Eucheuma cottonii seaweed in the waters of Ekas Bay (East Lombok) and Buwun Mas Village (West Lombok). The tools needed include a cool box, DO meter, refractrometer, digital camera. While the materials used include Eucheuma cottonii type seaweed, ice cubes, plastic, TCBS media. 
Journal of Fish Health Vol. 1 (1) - Juni 2021

Setyowati and Cokrowati (2021)

https://doi.org/10.29303/jfh.v1i1.164

\section{Seaweed Sampling Process}

Seaweed samples were taken randomly in Ekas Bay (East Lombok) and the waters of Buwun Mas Village (West Lombok). Samples are put in plastic and labeled. The sample is put into a cool box that has been given ice cubes so that the seaweed sample remains fresh during the transportation process.

Vibrio Identification

Vibrio identification was carried out at the Sekotong Marine Cultivation Fisheries Center. Eucheuma cottonii samples used for identification of vibrio bacteria are those with a white thallus tip. Bacterial culture of Eucheuma cottonii samples was carried out using a selective medium for Vibrio, namely TCBS. Identification of bacteria using biochemical tests. The biochemical test was carried out according to the method carried out by Bergey and Holt (1994).

\section{RESULT}

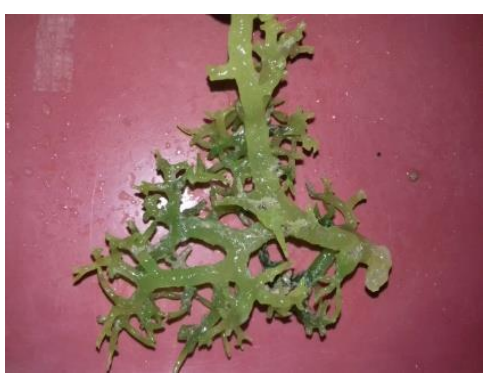

Figure 1. The Tip of the Seaweed Thallur Turns White from Ice-Ice Disease

Seaweed affected by ice-ice disease showed the characteristics of the tip of the thallus being whitish, then the thallus was broken. This is in accordance with the opinion of Lundsor (2002) in Fitrian (2015) that the thallus affected by ice-ice has a pale white and broken thallus characteristic. Table of results of Bacterial Analysis of Vibrio sp. on Seaweed are presented in Table 1 . While the results of the analysis of the quality of seaweed cultured water are presented in Table 2 .

Table 1. Results of Bacterial Analysis of Vibrio sp. on Seaweed

\begin{tabular}{|c|c|c|c|}
\hline No. & Sample Origin & Types of Seaweed & Vibrio Test Results \\
\hline 1 & Ekas & Eucheuma striatum & $\begin{array}{l}\text { Vibrio alginolytticus, Vibrio } \\
\text { parahaemolitycus }\end{array}$ \\
\hline 2 & Buwun Mas & Eucheuma cottoni & $\begin{array}{l}\text { Vibrio parahaemolyticus, Vibrio } \\
\text { alginolyticus, Vibrio damsela }\end{array}$ \\
\hline
\end{tabular}

Table 2. Analysis of Seaweed Cultivation Water Quality

\begin{tabular}{lllll}
\hline \multicolumn{1}{c}{ Location } & \multicolumn{4}{c}{ Water Quality Parameters } \\
\cline { 2 - 5 } & Salinity (ppt) & DO $(\mathrm{ppm})$ & $\begin{array}{l}\mathrm{NH3} / \mathrm{NH} 4 \\
(\mathrm{mg} / \mathrm{L})\end{array}$ & $\mathrm{PO4}(\mathrm{mg} / \mathrm{L})$ \\
\hline Teluk Ekas & 38 & 9 & 0 & 0,03 \\
Desa Buwun Mas & 32 & 7 & 0,25 & 0,1 \\
\hline
\end{tabular}




\section{DISCUSSION}

$75 \%$ of Vibrio parahaemolyticus was found in seaweed which indicated ice-ice disease. In the Ekas Bay sample, this type of vibrio was found in all samples indicated to have been exposed to ice-ice. However, this type of vibrio was found to attack $50 \%$ of the samples indicated to be exposed to ice-ice. Meanwhile, Vibrio alginolyticus was found to attack $100 \%$ of seaweeds indicated by ice-ice both in Ekas Bay and Buwun Mas. This type of vibrio was also found in Fitrian's (2015) study which observed ice-ice disease on seaweed in Southeast Maluku. Vibrio damsiela was only found in $50 \%$ of samples in Buwun Mas. According to LingSong (1993), Vibrio damsiela can cause death in shrimp in Taiwan. The results of the research at Buwun Mas showed that this type of vibrio can cause ice-ice disease in Eucheuma cottonii seaweed.

According to Largo et al. (1999) in Tisera and Naguit (2009), bacterial attacks include Vibrio sp. can trigger ice-ice disease. Largo (2002) also stated that one of the causes of ice-ice disease in Kappaphycus/Eucheuma seaweed is Vibrio sp. Ice-ice disease according to Largo (2002) not only interferes with the growth and appearance of seaweed, but can also reduce the quality of carrageenan from seaweed by producing hydrolytic enzymes. Besides being caused by Vibrio bacteria, ice-ice disease is also caused by environmental factors/water quality (salinity, light intensity, temperature, nutrients).

Seaweed is cultivated in Ekas Bay using the longline method. According to SNI 7673.2.2011 (BSN 2011), the water quality standard for the longline method of Eucheuma cottoni seaweed cultivation is 28-33 ppt. According to Atmanisa et al. (2020), Eucheuma cottoni is one of the stenohaline seaweeds, high salinity fluctuations can affect the seaweed osmoregulation process. The results showed that the salinity in Ekas Bay exceeds the SNI standard, so that it can cause seaweed to be susceptible to disease.

Meanwhile, in Buwun Mas Village, Eucheuma cottonii is maintained using the base/offbottom peg method. According to SNI 7673.1:2011 (BSN 2011), the salinity standard for the cultivation of Eucheuma cottoni with the off-bottom method is about 28-34 ppt. For salinity in Buwun Mas Village, it still meets the requirements for seaweed cultivation because it is still within the allowed range, which is $32 \mathrm{ppt}$.

The dissolved oxygen content in Eucheuma cottoni cultivation in Ekas Bay is $9 \mathrm{mg} / \mathrm{L}$. While the dissolved oxygen content obtained from observations in Buwun Mas Village is 7 $\mathrm{mg} / \mathrm{L}$. According to Sutamihardja (1978) in Atmanita et al. (2020), the normal oxygen content at sea level is $5.7-8.5 \mathrm{mg} / \mathrm{l}$. The oxygen content in the waters of Buwun Mas Village is still in normal condition. Meanwhile, the oxygen content in the waters of Ekas Bay exceeds normal, but is only $0.5 \mathrm{mg} / \mathrm{L}$ different from the threshold for dissolved oxygen content at sea level.

The content of phosphate (PO4) in the waters of Ekas Bay is $0.03 \mathrm{mg} / \mathrm{L}$, while in the waters of Buwun Mas it is $0.1 \mathrm{mg} / \mathrm{L}$. According to Atmanita et al. (2020), the concentration of phosphate required for algae growth is $0.018-0.090 \mathrm{mg} / \mathrm{L}$. Meanwhile, the highest limit for phosphate is $8.9-17.8 \mathrm{mg} / \mathrm{L}$ if nitrogen is in the form of nitrate. Therefore, the phosphate content in Ekas Bay and Buwun Mas waters is still in normal condition to support seaweed growth.

\section{CONCLUSION}

The results of the identification of vibrio in the sample of Eucheuma cottonii showed that vibrio bacteria were associated with ice-ice disease in seaweed. The types of vibrio 
Journal of Fish Health Vol. 1 (1) - Juni 2021

Setyowati and Cokrowati (2021)

https://doi.org/10.29303/jfh.v1i1.164

bacteria that cause ice-ice disease in samples in Ekas Bay and Buwun Mas are Vibrio parahaemolyticus, Vibrio alginolyticus, and Vibrio damsela.

\section{ACKNOWLEDGMENT}

Researchers would like to thank Mataram University that has been facilitating and supporting during this research.

\section{REFERENCES}

Atmanisa,A.,Mustarin,A.,Taufieq,N. A. S. 2020. Analisis Kualitas Air pada Kawasan Budidaya Rumput Laut Eucheuma Cottoni di Kabupaten Jeneponto. Jurnal Pendidikan Teknologi Pertanian. 6 (1): 11-22

Badan Standardisasi Nasional. 2011. Standar Nasional Indonesia Produksi Bibit Rumput Laut Kotoni (Eucheuma cottoni) - Bagian 1: Metode Lepas Dasar. 12p

Badan Standardisasi Nasional. 2011. Standar Nasional Indonesia. Produksi Bibit Rumput Laut Kotoni (Eucheuma cottoni) - Bagian 2: Metode Longline. 12p

Bergeys,D. H., Holt,J. G. 1994. Bergey's Manual of Determinative Bacteriology Ninth Edition. Williams and Wilkins. Baltimore

Bhernama, B. G. 2019. Analisa Karakteristik Karaginan Eucheuma cottonii asal Aceh Jaya menggunakan Pelarut Alkali (KOH dan NaOH). AMINA. 1 (2): 59-66.

Dinas Kelautan dan Perikanan Provinsi NTB. 2015. Laporan Akhir Penyusunan Masterplan Pengembangan Perikanan Budidaya tahun 2015-2019 Provinsi Nusa Tenggara Barat. $82 \mathrm{p}$.

Fitrian, T. 2015. Hama dan penyakit (Ice-Ice) pada Budidaya Ruput Laut Studi Kasus: Maluku Tenggara. Oseana. 9 (4): 1-10

Kementerian Kelautan dan Perikanan. 2018. Produktivitas Perikanan Indonesia. Forum Merdeka Barat 9 Kementerian Komunikasi dan Informatika.

Largo, D. B. 2002. Recent Development in Seaweed Diseases. SEAFDEC Aquaculture Department. Filipina. p: 1-9

Ling-Song,Y.,Cheng,W., Hsing-Wang, C. 1993. Isolation and Characterization of Vibrio damsel Infectious for Cultured Shrimp in Taiwan. Journal of Invertebrata Pathology. 61 (1): 2431

Setyowati, D. N. 2018. Buku Ajar Parasit dan penyakit Ikan. Pustaka Bangsa. Mataram 222p.

Setyowati,D. N.,Cokrowati, N., Rusdani, M. 2018. Penyakit pada Rumput Laut Hasil Budidaya di Lombok, Nusa Tenggara Barat. Bio Wallacea. Jurnal Ilmiah IImu Biologi. 1 (1) : 119124.

Tisera, W. N., Naguit, M. R. A. 2009. Ice-Ice Disease Occurance in Seaweed Farms in Bais Bay, Negros Oriental and Zamboanga Del Norte. The Treshold. 4: 1-16 